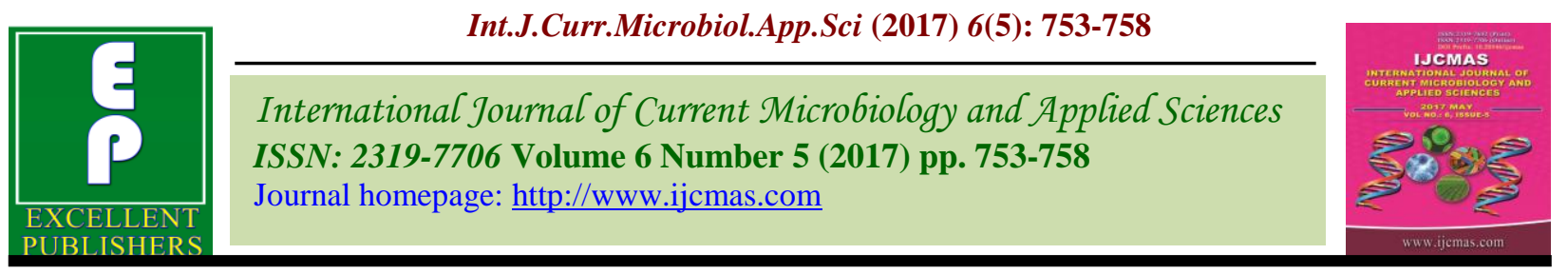

Original Research Article

https://doi.org/10.20546/ijcmas.2017.605.085

\title{
Influence of Nitrogen Application Frequency on Yield and Economics of Drip Irrigated Potato (Solanum tuberosum L.) Cv. Kufri Bahar
}

\author{
Vikram Ghiyal* and A.K. Bhatia \\ Department of Vegetable Science, College of agriculture, \\ CCS Haryana Agricultural University, Hisar-125004, India \\ *Corresponding author
}

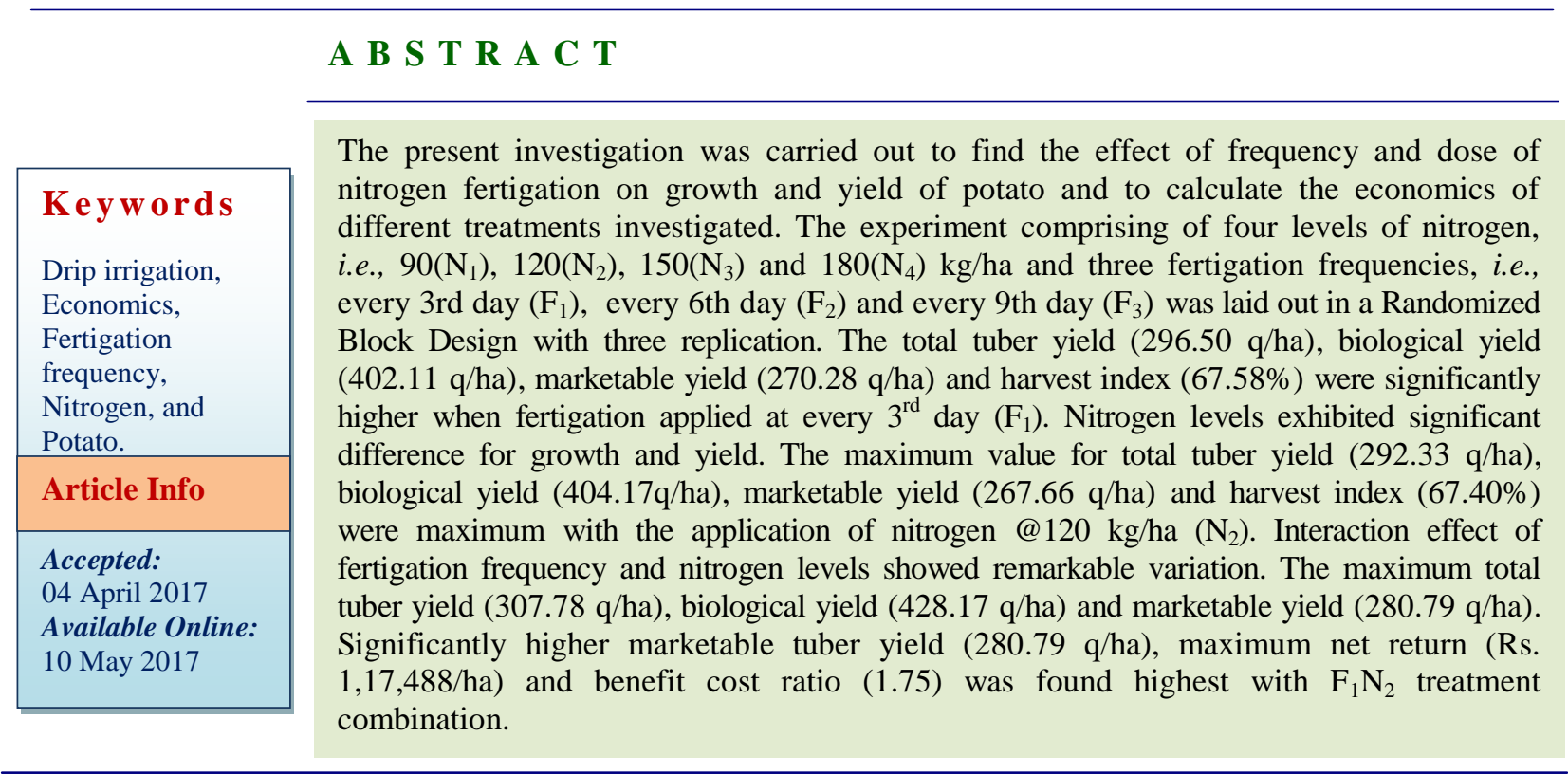

\section{Introduction}

Potato (Solanum tuberosum L.) is the third most important food crop after rice and wheat is being grown and consumed in all over the world (FAO, 2014; Singh, 2015). India has the largest irrigation network in the world; its irrigation efficiency has not been more than $40 \%$. The modern method of irrigation provides scope to utilize water and fertilizer nutrients effectively by minimizing the losses of irrigation water and plant nutrients in the form of deep percolation and surface runoff. Drip irrigation applies water directly on or below the soil surface near the root zone of plant and delivers the required quantity of water in relatively small amounts precisely to plant root zone through emitters placed along a low pressure delivery system. Drip irrigation also provides application of soluble fertilizers and other chemicals along with irrigation water. Among modern irrigation techniques, drip irrigation has been shown to be a more water efficient alternative than furrow irrigation for potato (Wang et al., 2011). In fertigation Nutrient use efficiency could be as high as $90 \%$ compared to 40 $60 \%$ in conventional methods. The amount of 
fertilizer lost through leaching can be as low as $10 \%$ in fertigation where as it is $50 \%$ in the traditional system. Adoption of microirrigation systems may help to increase the irrigated area, productivity of crops and water use efficiency. Inadequate $\mathrm{N}$ fertilization leads to poorer potato growth and yield while excessive $\mathrm{N}$ application leads to delayed maturity, poor tuber quality, and occasionally a reduction in tuber yield (Cerny et al., 2010). High level of $\mathrm{N}$ tends to reduce tuber development by promoting shoot growth while treatments which inhibit or reduce shoot growth, such as applications of a growth suppressor, promote tuber formation (Peres et al., 2005).

\section{Materials and Methods}

The field experiment was carried out at Vegetable Research Farm CCSHAU, Hisar during Rabi-season 2014-15. Hisar is situated at latitude of $29^{\circ} 10^{\prime} \mathrm{N}$, longitude of $75^{\circ} 46^{\prime} \mathrm{E}$ and height of 215.2 metres above mean sea level and falls in semi-arid and sub-tropical region with hot and dry summer and sever cold in winter. The soil was sandy loam in available organic carbon $(0.66 \%)$, available nitrogen (105 kg/ha), available phosphorus $(8.0 \mathrm{~kg} / \mathrm{ha})$ and available potash $(225 \mathrm{~kg} / \mathrm{ha})$ with $\mathrm{pH}$ of 8.3 . The air temperature $\left({ }^{\circ} \mathrm{C}\right)$, relative humidity (\%) and sum of precipitation $(\mathrm{mm})$ during the potato vegetation period at the experimental field are summarized in Figure 1. The experiment was laid out in randomized block design. The net plot size was two rows of eight-meter length each $(8.0 \times 1.2 \mathrm{~m})$. Farm yard manure (FYM) @ 50 t/ha was applied prior to field preparation and full dose of phosphorus and potash were applied as basal dose. Potato tubers of cv. Kufri Bahar were planted at $60 \times 20 \mathrm{~cm}$ spacing in the last week of October. Immediately after planting a furrow irrigation was given. The differential drip fertigation treatments were started 20 days after planting. The crop was subjected to four levels of nitrogen i.e. $\mathrm{N}_{1}: 90 \mathrm{~kg} / \mathrm{ha}, \mathrm{N}_{2}: 120$ $\mathrm{kg} / \mathrm{ha}, \mathrm{N}_{3}: 150 \mathrm{~kg} / \mathrm{ha}$ and $\mathrm{N}_{4}: 180 \mathrm{~kg} / \mathrm{ha}$. Each nitrogen level was coupled with three fertigation frequencies viz every $3^{\text {rd }}$ day in 30 split doses $\left(F_{1}\right)$, every $6^{\text {th }}$ day in 12 split doses $\left(F_{2}\right)$ and every $9^{\text {th }}$ day in 8 split doses $\left(F_{3}\right)$. Hence, twelve treatment combinations were used for conducting present study. The irrigation was applied at every $3^{\text {rd }}$ day though drip. The total tuber yield, marketable yield, biological yield, harvesting index and economics of the various treatments was recorded.

\section{Results and Discussion}

\section{Total tuber yield}

The total tuber yield (q/ha) was significantly influenced by fertigation frequency and nitrogen levels (Table 1). It is evident from the results that the maximum total tuber yield $(296.50 \mathrm{q} / \mathrm{ha})$ was obtained with $\mathrm{F}_{1}$ (fertigation on every $3^{\text {rd }}$ day) followed by $\mathrm{F}_{2}$ (fertigation at every $6^{\text {th }}$ day) and minimum $\left(268.00 \mathrm{q} / \mathrm{ha}\right.$ ) with $\mathrm{F}_{3}$ (fertigation on every $9^{\text {th }}$ day). The maximum $(292.33 \mathrm{q} / \mathrm{ha})$ total tuber yield was observed with $\mathrm{N}_{2}$ (nitrogen 120 $\mathrm{kg} / \mathrm{ha}$ ), while minimum yield (264.69 q/ha) was recorded in $\mathrm{N}_{4}$ (nitrogen $180 \mathrm{~kg} / \mathrm{ha}$ ). The tuber yield also varied significantly due to the interaction of fertigation frequency and nitrogen levels. Interaction effect revealed maximum $(296.50 \mathrm{q} / \mathrm{ha})$ total tuber yield with $\mathrm{F}_{1} \mathrm{~N}_{2}$ followed by $\mathrm{F}_{1} \mathrm{~N}_{3}$, while $\mathrm{F}_{3} \mathrm{~N}_{4}$ recorded lower $(252.80 \mathrm{q} / \mathrm{ha}$ ) total tuber yield. Kumar et al., (2006) reported that crop responded to nutrient application rate under drip fertigation with fertilizer level $\mathrm{F}_{1}$ (Fertigation levels $\mathrm{N}$ 187: $\mathrm{P}_{2} \mathrm{O}_{5} 63: \mathrm{K}_{2} \mathrm{O} 125 \mathrm{~kg} / \mathrm{ha}$ ) producing the highest tuber yield, followed by $\mathrm{F}_{2}$ (141:47:93 $\mathrm{kg} / \mathrm{ha})$ and $\mathrm{F}_{3} \quad(93: 32: 63 \mathrm{~kg} / \mathrm{ha})$. These findings are in conformity with the results of Khalak et al., (1993). Similarly, Badr et al., (2011) reported the higher tuber yield at 
higher nitrogen rate compared to the low nitrogen rate and average total yield across fertigation frequencies were 31.25 and 44.03 t/ha for 200 and $300 \mathrm{~kg} \mathrm{~N} / \mathrm{ha}$, respectively. Meyer and Marcum (1998) also reported a positive response of potato yield and quality to increasing $\mathrm{N}$ rate, and found that total yield was maximized with nitrogen @ 224 kg/ha. Behnam Etemad and Mansour Sarajuoghi (2012) showed that the interaction of different levels of $\mathrm{N}$ fertilizer $\times$ different of application times significantly affected tuber yield ( $\mathrm{P}$ $\leq 0.05)$. A distinct increase tubers yield was observed with $\mathrm{T}_{1}(424.12 \mathrm{Q} / \mathrm{ha})$ (Drip each row) and $\mathrm{T}_{2}(406.75 \mathrm{Q} / \mathrm{ha})$ (Drip each pair) during both the years and in pooled data (Kapadiya et al., 2013).

\section{Biological yield}

Interaction effect of nitrogen levels and fertigation frequency showed significant variation with respect to biological yield. The highest biological yield (428.17 q/ha) was observed with $\mathrm{F}_{1} \mathrm{~N}_{2}$ followed by $\mathrm{F}_{1} \mathrm{~N}_{3}$ (417.49 q/ha). However, least biological yield (379.09 q/ha) was recorded with $\mathrm{F}_{3} \mathrm{~N}_{4}$.

\section{Marketable tuber yield}

The findings revealed significant variations in marketable yield among different treatments. The present study showed that the highest marketable tuber yield $(270.28 \mathrm{q} / \mathrm{ha})$ was obtained with fertigation every $3^{\text {rd }}$ day and the minimum marketable yield (242.68 q/ha) was observed with fertigation on every $9^{\text {th }}$ day. In case of nitrogen levels, maximum marketable yield (267.66 q/ha) was observed with $\mathrm{N}_{2}$ (nitrogen $120 \mathrm{~kg} / \mathrm{ha}$ ) and the minimum ( $240.60 \mathrm{q} / \mathrm{ha}$ ) was reported with $\mathrm{N}_{4}$ (nitrogen $180 \mathrm{~kg} / \mathrm{ha}$ ). This might be attributed to nitrogen fertigation on every $3^{\text {rd }}$ day that increased vegetative growth and finally increased the marketable tuber yield. The present findings are in agreement with
Sandhu et al., (2008), who also reported that with the increase in fertilizer dose from 75 to 100,100 to 125 and 125 to $150 \%$ of RDF, there was significant increase in the yield, as well as marketable tuber yield.

Similarly Cook and Sander (1991) found that marketable yield and fruit size of subsurface drip-irrigated tomato were significantly higher with daily compared with biweekly or monthly fertigation on a loamy sand soil.

\section{Harvest index}

In the present investigation, there was significant difference for harvest index among the different fertigation frequency and nitrogen levels. The maximum harvest index $(67.58 \%)$ was recorded with fertigation at every $3^{\text {rd }}$ day, while minimum harvest index $(64.40 \%)$ was resulted with fertigation at every $9^{\text {th }}$ day. In case of nitrogen levels, nitrogen application @ $120 \mathrm{~kg} / \mathrm{ha}$ resulted highest harvest index $(67.40 \%)$ and the lowest was obtained with $\mathrm{N}_{4}(64.01 \%)$. Interaction effect between the treatments found did not show significant effect on harvest index.

It was observed significantly lower at higher fertilizer dose. The present finding are in harmony with the result of Singh and Lal (2012) who reported that the harvest index increased with the increase in nitrogen dose up to $150 \mathrm{~kg} / \mathrm{ha}$ and potassium dose up to 100 $\mathrm{kg} / \mathrm{ha}$ in potato. Similarly Lalitha et al., (2000) and Sujatha et al., (2001) reported an increase in harvest index in potato with the increase in the nitrogen and potassium doses over control. Sasani et al., (2006) also reported that harvest index was maximum under drip fertigation with $100 \%$ recommended dose of $\mathrm{N}$ and $\mathrm{K}_{2} \mathrm{O}$, whereas, the lowest harvest index (62.7\%) was recorded in the treatment receiving $40 \%$ of recommended dose of $\mathrm{N}$ and $\mathrm{K}_{2} \mathrm{O}$ fertigation. 
Table.1 Effect of fertigation frequency and nitrogen levels on total tuber yield (q/ha), biological yield, marketable yield and harvesting index in Potato cv. Kufri Bahar

\begin{tabular}{|c|c|c|c|c|c|}
\hline $\mathrm{N}$ rate & Fertigation & $\begin{array}{l}\text { Total tuber } \\
\text { yield (q/ha) }\end{array}$ & $\begin{array}{c}\text { Biological yield } \\
\text { (q/ha) }\end{array}$ & $\begin{array}{l}\text { Marketable } \\
\text { yield (q/ha) }\end{array}$ & $\begin{array}{c}\text { Harvesting } \\
\text { index }(\%)\end{array}$ \\
\hline \multirow{3}{*}{$90\left(\mathrm{~N}_{1}\right)$} & $\overline{F_{1}}$ & 296.95 & 404.58 & 268.31 & 67.23 \\
\hline & $\mathbf{F}_{2}$ & 275.13 & 380.46 & 248.03 & 66.15 \\
\hline & $\mathbf{F}_{3}$ & 269.93 & 376.28 & 242.86 & 63.51 \\
\hline \multirow{3}{*}{$120\left(\mathrm{~N}_{2}\right)$} & $F_{1}$ & 307.78 & 428.18 & 280.79 & 68.53 \\
\hline & $\mathbf{F}_{2}$ & 294.34 & 396.74 & 269.76 & 67.57 \\
\hline & $\mathbf{F}_{3}$ & 274.88 & 387.60 & 252.42 & 66.10 \\
\hline \multirow{3}{*}{$150\left(\mathrm{~N}_{3}\right)$} & $F_{1}$ & 299.06 & 417.49 & 271.47 & 68.29 \\
\hline & $F_{2}$ & 292.01 & 388.08 & 265.13 & 66.37 \\
\hline & $\mathbf{F}_{3}$ & 274.38 & 385.05 & 248.26 & 65.94 \\
\hline \multirow{3}{*}{$180\left(\mathrm{~N}_{4}\right)$} & $\mathbf{F}_{1}$ & 282.22 & 358.21 & 260.56 & 66.25 \\
\hline & $\mathbf{F}_{2}$ & 259.04 & 375.11 & 234.06 & 63.74 \\
\hline & $\mathbf{F}_{3}$ & 252.80 & 367.43 & 227.19 & 62.03 \\
\hline \multirow{7}{*}{ Mean } & $\mathrm{N}_{1}$ & 280.67 & 387.11 & 253.07 & 65.63 \\
\hline & $\mathbf{N}_{2}$ & 292.33 & 404.17 & 267.66 & 67.40 \\
\hline & $\mathbf{N}_{3}$ & 288.48 & 396.87 & 261.62 & 66.87 \\
\hline & $\mathbf{N}_{4}$ & 264.69 & 366.92 & 240.60 & 64.01 \\
\hline & $F_{1}$ & 296.50 & 402.11 & 270.28 & 67.58 \\
\hline & $\mathbf{F}_{2}$ & 280.13 & 385.10 & 254.25 & 65.96 \\
\hline & $\mathbf{F}_{3}$ & 268.00 & 379.09 & 242.68 & 64.40 \\
\hline \multirow{3}{*}{$\mathrm{CD}$ at $5 \%$} & Frequency & 2.85 & 3.75 & 3.78 & 1.41 \\
\hline & Nitrogen & 3.29 & 4.33 & 4.36 & 1.63 \\
\hline & $\mathbf{F} \times \mathbf{N}$ & 5.71 & 7.51 & 7.56 & NS \\
\hline
\end{tabular}

Table.2 Economics and net returns of different treatments in Potato cv. Kufri Bahar

\begin{tabular}{|c|c|c|c|}
\hline Treatments & yield (t/ha) & Net returns(Rs/ha) & B:C ratio \\
\hline Every 3 $\mathbf{3}^{\text {rd }}$ day $\left(\mathbf{F}_{\mathbf{1}}\right)$ & \multicolumn{3}{|l|}{} \\
\hline $\mathrm{N}_{1}(90 \mathrm{~kg})$ & 29.19 & 111887 & 1.66 \\
\hline $\mathrm{N}_{2}(120 \mathrm{~kg})$ & 30.77 & 117488 & 1.75 \\
\hline $\mathrm{N}_{3}(150 \mathrm{~kg})$ & 27.43 & 111355 & 1.67 \\
\hline $\mathrm{N}_{4}(180 \mathrm{~kg})$ & 25.27 & 87522 & 1.29 \\
\hline Every 6 $\mathbf{6}^{\text {th }}$ day $\left(\mathbf{F}_{\mathbf{2}}\right)$ & \multicolumn{3}{|l|}{} \\
\hline $\mathrm{N}_{1}(90 \mathrm{~kg})$ & 29.68 & 97536 & 1.45 \\
\hline $\mathrm{N}_{2}(120 \mathrm{~kg})$ & 29.42 & 109421 & 1.63 \\
\hline $\mathrm{N}_{3}(150 \mathrm{~kg})$ & 27.50 & 108393 & 1.62 \\
\hline $\mathrm{N}_{4}(180 \mathrm{~kg})$ & 25.89 & 83787 & 1.24 \\
\hline Every 9 $\mathbf{9}^{\text {th }} \mathbf{d a y}\left(\mathbf{F}_{\mathbf{3}}\right)$ & 27.48 & 97083 & 1.44 \\
\hline $\mathrm{N}_{1}(90 \mathrm{~kg})$ & 26.98 & 101430 & 1.50 \\
\hline $\mathrm{N}_{2}(120 \mathrm{~kg})$ & 29.89 & 98117 & 1.47 \\
\hline $\mathrm{N}_{3}(150 \mathrm{~kg})$ & 28.21 & 94784 \\
\hline $\mathrm{N}_{4}(180 \mathrm{~kg})$ & $*$ Price of produce $=$ Rs. 6000 per tonne. \\
\hline
\end{tabular}


Fig.1 The air temperature $\left({ }^{\circ} \mathrm{C}\right)$, relative humidity $(\%)$ and sum of precipitation $(\mathrm{mm})$ during the potato vegetation period at the experimental field

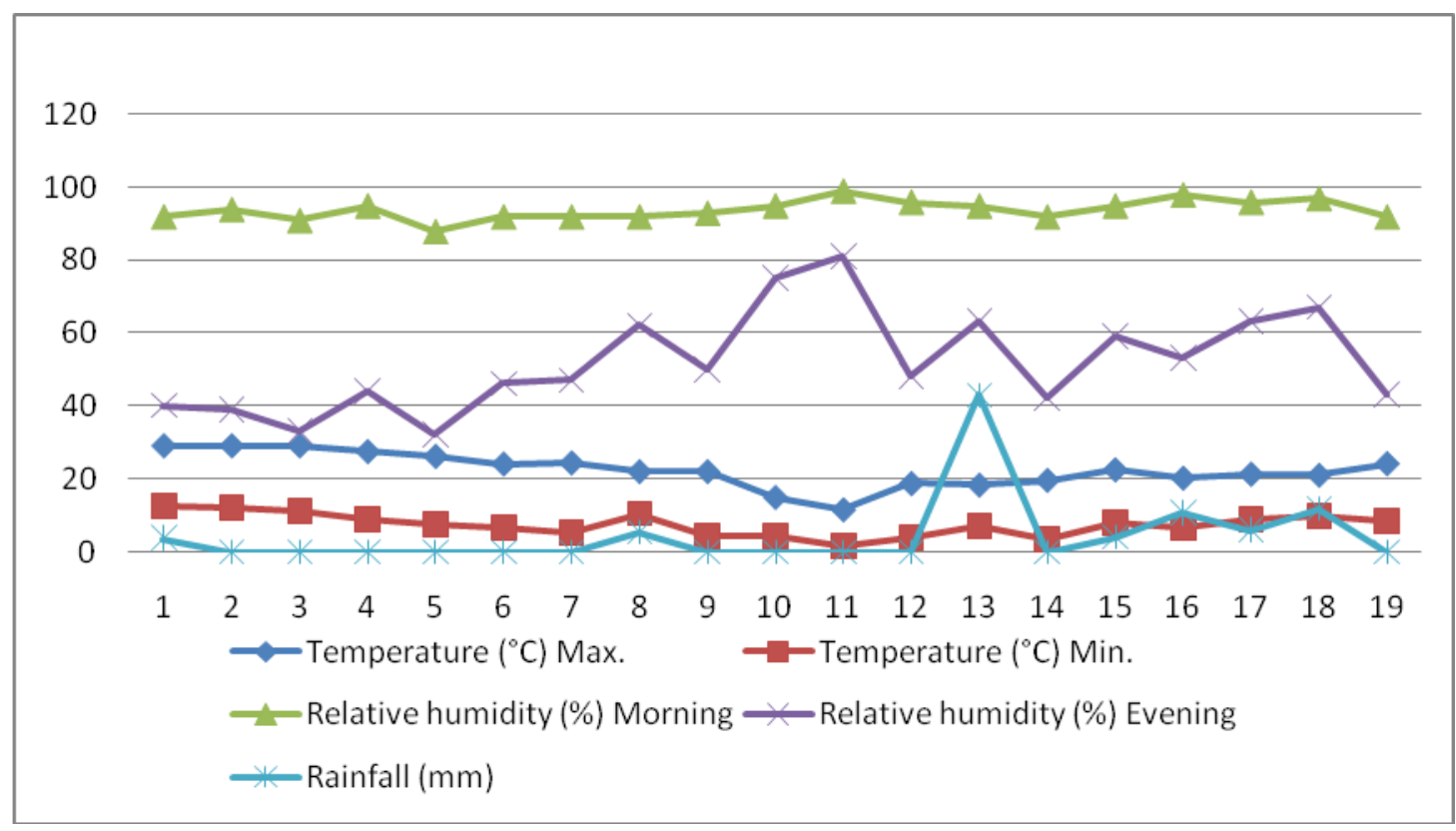

\section{Economics of various treatments}

Fertigation on every $3^{\text {rd }}$ day with nitrogen 120 $\mathrm{kg} / \mathrm{ha}$ showed maximum net return and $\mathrm{B}$ : C ratio (Rs.1, 17,488 and 1.75) followed by the fertigation at every $3^{\text {rd }}$ day with nitrogen 150 $\mathrm{kg} / \mathrm{ha}$ (Rs. 1, 11,355 and 1.67). Patel et al., (2012) found that fertilizer level $F_{2}$ (75\% of recommended $\mathrm{N}$ and $\mathrm{K}$ ) had significantly higher BCR of 1.56, but it was at par with $\mathrm{F}_{3}$ (100\% of recommended $\mathrm{N}$ and $\mathrm{K}$ ) and also studied that significantly higher BCR (1.75) was under treatment combination $\mathrm{I}_{2} \mathrm{~F}_{2}$ (Drip in each pair $+100 \% \mathrm{RD}$ of $\mathrm{N}$ and $\mathrm{K}$ ), it was statistically at par (1.73) with treatment combination $\mathrm{I}_{2} \mathrm{~F}_{3}$ (Drip in each pair $+50 \%$ $\mathrm{RD}$ of $\mathrm{N}$ and $\mathrm{K}$ ).

Tiwari et al., (2010) also observed that highest benefit-cost ratio of 2.11 was in case of treatment $\mathrm{F}_{4}(100 \% \mathrm{RD}$ of $\mathrm{N})$ followed by the treatment $\mathrm{F}_{3}(80 \% \mathrm{RD}$ of $\mathrm{N})$. Kapadiya et al., (2013) found that the highest BCR of 1.64 was obtained under irrigation method $T_{2}$ (Drip each pair) and irrigation through perforated pipes $\left(\mathrm{T}_{3}\right)$ achieved the lowest benefit cost ratio (1.31) compare to other irrigation treatments.

In conclusion, based on the findings of one season study it may be concluded that when nitrogen@120 kg/ha was applied through drip irrigation every 3rd day gave significantly higher tuber yield (307.78 q/ha). Maximum net return (Rs. 1, 17,488/ha) and benefit cost ratio (1.75) was also found highest with the same treatment combination.

\section{References}

Badr, M.A., Taalab, A.S. and El-Tohamy, W.A. 2011. Nitrogen application rate and fertigation frequency for drip-irrigated potato (Solanum tuberosum). Australian J. Basic and Appl. Sci., 5(7): 817-825.

Behnam Etemad and Mansour Sarajuoghi. 2012. Study of the Effect of Different Levels and Application Timing of Nitrogen Fertilizer on Yield and Number of Potato Tuber of Agria in Ghorveh, Iran. Annals of Biol. Res., 3(3): 1385-1387.

Cerny, J., Balk, J., Kulhnek Kulhanek, M., 
Casova, K., Nedved, V. 2010. Mineral and organic fertilization efficiency in long-term stationary experiments. Plant Soil Env., 56: 28-36.

Cook, W.P. and Sanders, D.C. 1991. Nitrogen application frequency for drip irrigated tomatoes. Hort. Sci., 26: 250-52.

FAO statistical databases FAOSTAT. 2014. http://faostat3.fao.org/ Accessed.

Gildemacher, P., Schulte-Geldermann, E., Borus, D., Demo, P., Kinyae, P., Mundia, P., Struik, P.C. 2011 Seed potato quality improvement through positive selection by smallholder farmers in Kenya. Potato Res., 54: 253-266.

Kapadiya, H.N., K.B. Gohil, S.A. Trivedi. 2013. Potato Crop Performance and Economics under Various Irrigation Systems. Indian J. Res., 3: 103-104.

Khalak, A. and Kumaraswamy, A.S. 1993. Nutrient uptake and tuber yield of potato as influenced by irrigation and mulching under scare water condition in Alfi soil. J. Indian Potato Assoc., 18: 35-39.

Kumar, S., Mandal, G., Asrey, R. and Singh, R. 2006. Influence of irrigation and fertigation on yield, production efficiency and economic returns of drip irrigated potato under semiarid environment. Potato J., 33(3-4): 126130.

Lalitha, B.S., Nagraj, K.H., Amarananjundeswar, H. and Lalitha, K.C. 2000. Economics of potassium and sulphur levels on yield and quality of potato raised from seed tuber and true potato seed (TPS). Mysore J. Agri. Sci., 34(1): 61-65 (2000).

Meyer, R.D. and Marcum, D.B. 1998. Potato yield, petiole nitrogen and soil nitrogen response to water and nitrogen. Agronomy J., 90(3): 420-429.

Patel, D.K., Patel, B.M., Patel, P.T., Patel, D.M. and Patel, B.J. Influence of irrigation methods along with nitrogen and potash management on yield and nutrient uptake by potato (Solanum tuberosum L.). Agri. Sci.
Digest, 32(1): 38-42.

Peres, L.E.P., Carvvalho, R.F., Zsogon, A., et al. 2005. Grafting of tomato mutants onto potato rootstocks: an approach to study leaf-derived signaling on tuberization. Plant Sci., 160: 680-688.

Sandhu, A.S., Bhutani R.D. and Khurana, S.C. 2008. Effect of planting dates and fertilizer doses on plant growth and yield attributes of potato. Haryana J. Hort. Sci., 37(1-2): 157159.

Sasani, G.V., Patel, C.K., Patel, R.N., Patel, N.H. and Patel, S.H. 2006. Efficient use of water and fertilizers through drip fertigation in potato (Solanum tuberosum). Potato J., 33 (3-4): 131-133.

Singh, H.P. 2008. Policies and strategies conducive to Potato development in Asia and the Pacific region. In: Proceedings of the Workshop to Commemorate the International Year of Potato- 2008 held on 6 May 2008 at Bangkok, Thailand, pp. 18-29.

Singh, S.K. and Lal, S.S. 2012. Effect of potassium nutrition on potato yield, quality and nutrient use efficiency under varied levels of nitrogen application. Potato J., 39(2): 155-165.

Sujatha, N.T., Krishnappa, K.S. and Chandregowda, M. 2001. Dry matter accumulation, primary nutrient content and uptake in potato in relation to fertility levels. Mysore J. Agri. Sci., 35(2): 108-114.

Tiwari, K.N., Maji, M.K., Biswas, U. and Mal, P.K. 2010. Studies on nitrate-nitrogen movement under Sub-surface drip irrigation in potato. J. Agri. Engi., Vol. 47(2).

Wang, F.X., Wu, X.X., Shock, C.C., Chu, L.Y., Gu, X.X., Xue, X. 2011. Effects of drip irrigation regimes on potato tuber yield and quality under plastic mulch in arid northwestern China. Field Crops Res., 122: 78-84.

\section{How to cite this article:}

Vikram Ghiyal and A.K. Bhatia. 2017. Influence of Nitrogen Application Frequency on Yield and Economics of Drip Irrigated Potato (Solanum tuberosum L.) Cv. Kufri Bahar. Int.J.Curr.Microbiol.App.Sci. 6(5): 753-758. doi: https://doi.org/10.20546/ijcmas.2017.605.085 